\title{
Morphology of seeds, seedlings, and young plants of Dimorphandra gardneriana Tul.
}

\section{Morfologia de sementes, plântula e planta jovem de Dimorphandra gardneriana Tul.}

\author{
Sueli da Silva Santos-Moura ${ }^{1 *}$; Rosemere dos Santos Silva²; Edna Ursulino Alves ${ }^{3}$; \\ Edilma Pereira Gonçalves ${ }^{4}$; Lenyneves Duarte Alvino de Araújo ${ }^{5}$; Magnólia \\ Martins Alves²; Paulo Costa Araujo ${ }^{6}$
}

\begin{abstract}
Dimorphandra gardneriana Tul. is a legume, the fruits of which are used in routine extraction by the pharmaceutical industry. The objective was to study the morphological aspects of seeds, germination, seedlings, and young plants of Dimorphandra gardneriana Tul. The study was conducted at the Laboratory of Seed Analysis (LAS), Center of Agricultural Sciences, Federal University of Paraíba (CCA-UFPB), Areia - PB. The external morphological characteristics observed of the seeds were color, texture, and consistency of the teguments; seed shape; hilum and micropyle position; color and thickness of raphe and other structures present; besides internal embryo characteristics (cotyledons, hypocotylradicle axis, plumule, and central cylinder); and presence of the endosperm. The seed imbibition curve was determined by the weight of the seeds over a period of $90 \mathrm{~h}$, evaluated every $6 \mathrm{~h}$, with germination being considered as the protrusion of the primary root, or the moment when the primary root breaks the integument, and normal seedlings were evaluated on the 5th day after sowing. Most of the morphological characteristics identified in the plants and seedlings of D. gardneriana resembled those observed for other species of the same genus. The seeds of D. gardneriana Tul., were medium sized, with an average length of $11.95 \mathrm{~mm}$, width of $5.33 \mathrm{~mm}$, and thickness of $4.3 \mathrm{~mm}$, unitegmic with a hard tegument, and impermeable to water. The process of imbibition of the seeds was initially slow and the three-phase curve of imbibition was not clear. The germination was epigeic and phanerocotiledonar and began on the 5th day after sowing.
\end{abstract}

Key words: Fava-danta. Forest species. Germination.

1 Prof ${ }^{a}$, Curso Técnico em Agropecuária no Instituto Federal de Alagoas, IFAL, Santana do Ipanema, Alagoas, AL, Brasil. E-mail: suelidasilvasantos@yahoo.com.br

2 Discentes, Curso de Doutorado do Programa de Pós-Graduação em Agronomia, Universidade Federal da Paraíba, Centro de Ciências Agrárias, CCA-UFPB, Areia, PB, Brasil. E-mail: rosyufpbio@hotmail.com; magecologia@hotmail.com

3 Prof ${ }^{a}$, Curso de Agronomia, Universidade Federal da Paraíba, Centro de Ciências Agrárias, CCA/UFPB, Areia, PB, Brasil. E-mail: ednaursulino@cca.ufpb.br

4 Prof ${ }^{a}$, Curso de Agronomia, Unidade Acadêmica de Garanhuns, Universidade Federal Rural de Pernambuco, UFRPE/UAG, Garanhuns, PE, Brasil. E-mail: edilmapq@hotmail.com

5 Prof $f^{a}$, Curso de Biologia, Universidade Federal da Paraíba, Centro de Ciências Agrárias, CCA/UFPB, Areia, PB, Brasil. E-mail: lenyneves@cca.ufpb.br

6 Dr. em Agronomia, Universidade Federal da Paraíba, Centro de Ciências Agrárias, CCA/UFPB. Areia, PB, Brasil. E-mail: pauloaraujo85@hotmail.com

* Author for correspondence 


\section{Resumo}

Dimorphandra gardneriana Tul. é uma leguminosa, cujos frutos são utilizados na extração de rutina para o abastecimento da indústria farmacêutica. Objetivou-se estudar os aspectos morfológicos das sementes, germinação, plântulas e planta jovem de Dimorphandra gardneriana Tul. O trabalho foi realizado no Laboratório de Análise de Sementes (LAS) do Centro de Ciências Agrárias da Universidade Federal da Paraíba (CCA-UFPB), Areia - PB. As características morfológicas externas das sementes observadas foram: cor, textura e consistência dos tegumentos, forma das sementes, posição do hilo e da micrópila, cor e espessura da rafe e outras estruturas presentes, além das características internas do embrião (cotilédones, eixo hipocótilo-radícula, plúmula, cilindro central) e presença de endosperma. A curva de embebição das sementes foi determinada através do peso das sementes por um período de 90 horas, com avaliações a cada seis horas, sendo a germinação considerada desde a protrusão da raiz primária, ou seja o momento em que a raiz primária rompe o tegumento e as plântulas normais avaliadas no quinto dia após a semeadura. A maioria das características morfológicas identificadas nas plântulas e plantas de $D$. gardneriana assemelha-se às observadas para outras espécies do mesmo gênero. As sementes de Dimorphandra gardneriana Tul., têm tamanho médio, comprimento médio de 11,95 mm, largura de 5,33 mm e espessura de 4,3 mm, são unitegumentadas, com tegumento duro e impermeável á água. O processo de embebição das sementes é inicialmente lento, não sendo visível a curva trifásica da embebição de forma clara, a germinação é epígea, fanerocotiledonar, com início no quinto dia após a semeadura.

Palavras-chave: Fava-d'anta. Espécie florestal. Germinação.

\section{Introduction}

The species Dimorphandra gardneriana Tul., well known as "faveira" or "fava d'anta," belongs to the Fabaceae family and is originally from the Cerrado and Caatinga biomes of Brazil (PIRES et al., 2010). It occurs naturally in the states of Maranhão, Piauí, Ceará, Pernambuco, Bahia, Pará, Goiás, Mato Grosso and Minas Gerais (MONTANO et al., 2007). Its fruit is a flattened, indehiscent legume, with an irregular surface, rounded apex and base, green coloration, varying from dark brown to almost black when at the ripening stage, measuring up to $15 \mathrm{~cm}$ in length (RIBEIRO-SILVA et al., 2012), and is of economic importance as a raw material for the extraction of rutin, an important flavonoid with antioxidant properties and anti-inflammatory effects (MONTANO et al., 2007).

The study of the morphology of seeds, seedlings, and young plants assists in the botanical identification of species, interpretation of laboratory tests, recognition of the species in soil seed banks and forest formations, contributes to the study of dispersion and succession and regeneration mechanisms of the species (MELO et al., 2004).
The biometric characterization of seeds is important to differentiate the intensity of variation in species related to environmental factors, such as population reactions when established in another environment (RODRIGUES et al., 2006).

Seeds have considerable external and internal diversity owing to varying strategies of dispersion; therefore, the study of their morphology constitutes an important tool for species identification (GROTH; LIBERAL, 1988) and facilitates research in the germination of the seeds by ensuring the correct interpretation of germination tests (ABUD et al., 2012).

The knowledge of the morphological characteristics of the seedlings in the initial stages of development allows the identification of plants at a young phase and differentiation between very similar species, which contributes to studies of natural regeneration, helps in the understanding of the dynamics of plant populations, and in the recognition of successional stages in forests (DONADIO; DEMATTÊ, 2000; FERREIRA et al., 2001). 
The study of water absorption by seeds provides information about the germinative behavior as the three-phase pattern and the speed of water absorption do not occur similarly in seeds of different species. Albuquerque et al. (2009) state that the variation in the imbibition velocity occurs due to the characteristics of the integument, especially, the level of permeability and the chemical composition of the reserve tissue.

Morphological studies to identify fruits, seeds, seedlings, and young plants of species of the Fabaceae family were carried out by Duarte et al. (2015) in Albizia edwallii (Hoehne) Barneby \& J.W.Grimes, Ferreira and Barretto (2015) in Caesalpinia echinata Lam., Ribeiro et al. (2015) in Parkia gigantocarpa Ducke, and Reis et al. (2016) in Apuleia molaris Spruce ex Benth., as well as in the Dimorphandra genus by Ferreira et al. (2001) studying Dimorphandra mollis Benth. and by Lopes and Matheus (2008) in Dimorphandra wilsonii Rizz.; however, there is no information on the morphological characteristics of the species targeted in this study. Therefore, the objective was to study germination and the morphology of seeds, seedlings, and young plants of D. gardneriana Tul.

\section{Material and Methods}

The fruits of Dimorphandra gardneriana Tul. at the ripening stage, with a dark brown color, were harvested from 10 different mother trees located in forest remnants near the city of Jardim $\left(07^{\circ} 34^{\prime} 57^{\prime \prime} \mathrm{S}\right.$, $\left.39^{\circ} 17^{\prime} 53^{\prime \prime \prime} \mathrm{W}\right)$ and Crato $\left(07^{\circ} 14^{\prime} 03^{\prime \prime} \mathrm{S}, 39^{\circ} 24^{\prime} 34^{\prime \prime}\right.$ $\mathrm{W})$, in the Ceará state of Brazil. The seeds were processed on site (fruits were manually opened with the aid of a sledgehammer to extract the seeds), packed in polyethylene bags, and transported at ambient temperature to the Laboratory of Seed Analysis (LAS) belonging to the Department of Plant and Environmental Sciences, Center of Agricultural Sciences, Federal University of Paraíba. The seeds were stored in the same containers and kept in closed plastic buckets in a cold room at 15
${ }^{\circ} \mathrm{C}$ until the experiment was carried out. The study of the morphology and biometry was conducted in November 2015 and the following evaluations were performed.

Seed biometry - The length, width, and thickness of 100 seeds were measured with the aid of a precision pachymeter with an accuracy of $0.01 \mathrm{~mm}$. The length was measured from the base to the apex, the width and thickness were measured at the midline of the seeds, and the results were expressed in millimeters.

External and internal morphology of the seeds - Fifty seeds were prepared on the side opposite to the hilum and immersed in distilled water for $48 \mathrm{~h}$ to facilitate the removal of the tegument. Besides the evaluation of the intact seed, the tegument was removed, and the internal structures of the seed were analyzed with the aid of a stereoscopic magnifying glass (Model Czm4). For a better visualization of the embryonic axis, a longitudinal cut was made in the embryo using a scalpel, aiming at an adequate observation of the internal structures of the seed.

The external morphological characteristics of the seeds observed were the color, texture and consistency of the teguments, seed shape, hilum and micropyle position, raphe thickness, and other structures present. The internal characteristics observed were the embryo (cotyledons, hypocotylradicle axis, plumule, and central cylinder) and presence of endosperm. The terminology used is in accordance with Ferreira et al. (2001), Damião Filho (2005), Lopes and Matheus (2008), Brasil (2009b), and Appezzato-da-Glória and CarmelloGuerreiro (2012).

Determination of the moisture content - was carried out before soaking the seeds by the oven method at $105 \pm 3{ }^{\circ} \mathrm{C}$ for $24 \mathrm{~h}$ (BRASIL, 2009a), using four replicates of 10 seeds each and the results were expressed as a percentage.

Imbibition curve - was determined with 100 seeds, divided into four replicates of 25 seeds each, which were distributed on two sheets of paper 
towels, covered with a third, and organized in the form of a roller. The paper towel was moistened with distilled water equivalent to 2.5 times the mass of the dried paper. Afterwards, the rolls were packed in $0.04 \mathrm{~mm}$ thick, transparent plastic bags, to avoid loss of water by evaporation and placed in a Biological Oxygen Demand (BOD) germinator at an alternating temperature of 20-30 ${ }^{\circ} \mathrm{C}$ (URSULINO, 2013). Before the distribution of the seeds on the substrate, the four replicates were weighed to obtain the initial weight and then, weights were measured at the following periods: 1 , $2,3,4,5,6,12,18,24,30,36,42,48,54,60,66$, $72,78,84$, and $90 \mathrm{~h}$. The imbibition was determined as a function of seed weight increase and seed weight difference at each soaking time (mass in grams). The monitoring of seed weight was stopped when the emergence of primary root in some seeds was observed, characterizing the third stage of germination, according to the methodology adapted from Albuquerque et al. (2009).

Germination curve - After the emergence of the primary root in some seeds, the imbibition study was completed and the evaluation of germination was started. This occurred after $90 \mathrm{~h}$ of imbibition, characterized by the elongation of the embryonic axis, and evaluations were performed every $6 \mathrm{~h}$ of seeds showing the emergence of the primary root, ending at $150 \mathrm{~h}$ when the roots from all the seeds had emerged. Germination was considered as the protrusion of the primary root and counting of normal seedlings was performed on the 5 th day after the initiation of the test, where the development of the primary root and hypocotyl was verified as the emergence of the protophylls, based on a modified version of the method reported by Albuquerque et al. (2009).

\section{Morphological description of germination,} seedlings, and young plants - In parallel to the germination and seedling formation evaluations, structures were described at each stage of development, with the seedling stage being considered as the time from the emergence of the hypocotyl to the formation of the protophylls, while presence of fully expanded leaves were considered characteristics of the young plant.

The vegetative elements described and illustrated were the root (main and secondary), collar, hypocotyl, cotyledons, epicotyl, prophyll (1st and 2nd order), and stem and the morphological characters observed were enlarged or reduced as necessary. The structures were photographed with a Sony digital camera (Cyber-shot DSC-W320) with the naked eye or with the aid of a stereoscopic magnifying glass (Model Czm4).

For the evaluation of the young plant stage, 100 seeds were sown in a plastic tray $(49 \times 33 \times 7 \mathrm{~cm}$ in length, width, and depth, respectively) drilled at the bottom, with a seeding depth of $2 \mathrm{~cm}$, containing vermiculite substrate moistened at $60 \%$ field capacity and kept in the shade for $15 \mathrm{~d}$. Subsequently, the tray was placed in a greenhouse and irrigated daily for another $45 \mathrm{~d}$ and the evaluation of the morphological characteristics of the young plant were performed $60 \mathrm{~d}$ after sowing, following the methodology adapted from Braz et al. (2012).

\section{Statistical procedures}

The data obtained from the biometrics (length, width, and thickness) of the seeds were subjected to descriptive statistical analysis using the statistical program Sisvar 5.6 (FERREIRA, 2011), calculating the mean, standard deviation, variance, coefficient of variance, maximum values, and minimum and relative frequency.

\section{Results and Discussion}

\section{Seed biometry}

The distribution of the relative frequency of the length, width, and thickness of seeds of Dimorphandra gardneriana Tul. is shown in Figure 1, where a variation of 8.56 to $14.5 \mathrm{~mm}$ was observed in the length (Figure 1A). However, the 
most frequent values were observed in the intervals of 10.94 to $12.13 \mathrm{~mm}$, totaling $50 \%$ of the evaluated seeds. In relation to the width (Figure 1B), a range from 4.13 to $5.8 \mathrm{~mm}$ was observed in $88 \%$ of the analyzed seeds, while the thickness (Figure 1C) showed a small variation, with approximately $85 \%$ of the seeds ranging from 3.92 to $4.49 \mathrm{~mm}$.

Figure 1. Relative frequency distribution of length (A), width (B) and thickness (C) of D. gardneriana seeds.

A

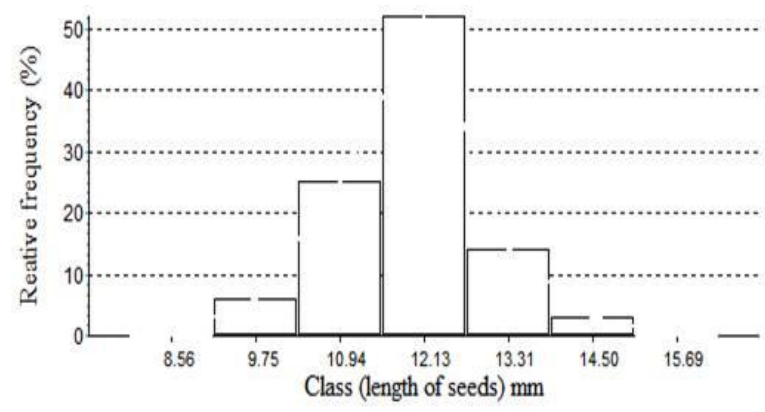

B

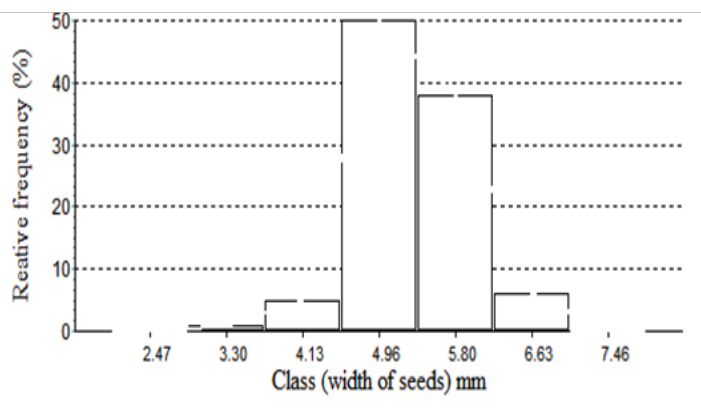

$\mathrm{C}$

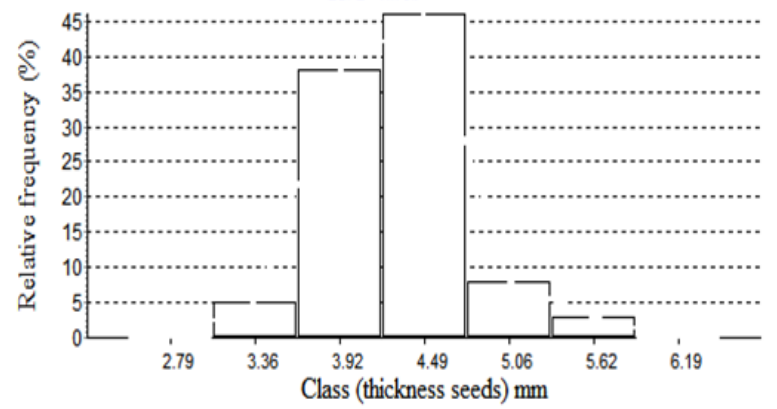

The width and thickness of the seeds showed small variations, as most of the analyzed data were grouped into two classes. Fifty percent of the values observed for length were grouped in five classes; however, $50 \%$ of the analyzed data were grouped in only one class. A small difference was observed in this characteristic, as the difference between the values grouped in the other classes was low.

The number of classes used allowed the identification of low variability in these characteristics, as the frequency distribution must have an adequate number of classes in order not to prejudice the interpretation of the phenomena under study. Thus, the grouping of the data into classes helped visualize the low variation between the length, width, and thickness in the seeds of $D$. gardneriana.
In seeds of Erythrina velutina Willd., these characteristics were also slightly variable, with a mean length of $12.54 \mathrm{~mm}$ (ranging from 10.83 to $13.96 \mathrm{~mm}$ ), mean width of $8.15 \mathrm{~mm}$ (ranging from 7.13 to $9.32 \mathrm{~mm}$ ), and mean thickness of $7.66 \mathrm{~mm}$ (ranging from 6.54 to $8.64 \mathrm{~mm}$ ) and seeds of 12.08$12.71,8.01-8.44$, and $7.38-7.80 \mathrm{~mm}$ in length, width, and thickness, respectively, predominant (SILVA et al., 2008).

On the other hand, mean values for length (12 to $21 \mathrm{~cm}$ ), width (6.0 to $9.5 \mathrm{~mm}$ ), and thickness (1.0 to $2.0 \mathrm{~mm}$ ) were found in seeds of Apuleia leiocarpa (Vogel) J.F.Macbr. with a certain variation, probably owing to the genetic variability between matrices and the influence of environmental factors during its development (FELIPPI et al., 2012). 
A mean value of $11.95 \mathrm{~mm}$, maximum of 14.50 $\mathrm{mm}$, minimum of $9.75 \mathrm{~mm}$, an amplitude of 4.75 $\mathrm{mm}$, and coefficient of variation of $7.92 \%$ was observed in the length of D. gardneriana seeds; while the average width was $5.33 \mathrm{~mm}$, with a maximum value of $6.63 \mathrm{~mm}$, minimum of $3.30 \mathrm{~mm}$, amplitude of $3.30 \mathrm{~mm}$, and with a coefficient of variation of $9.76 \%$. The mean seed thickness was $4.30 \mathrm{~mm}$ and maximum and minimum values were 5.63 and $3.36 \mathrm{~mm}$, respectively, with a coefficient of variation of $9.97 \%$ (Table 1 ).

Table 1. Descriptive statistics of dimensions (length, width and thickness) of D. gardneriana seeds.

\begin{tabular}{lrcc}
\hline \multirow{2}{*}{ Statistical parameters } & Length & Width & Thickness \\
\cline { 2 - 4 } & & $\mathrm{mm}$ & \\
\hline Mean & 11.95 & 5.33 & 0.30 \\
Standard deviation & 0.95 & 0.52 & 0.43 \\
Varience & 0.90 & 0.27 & 0.18 \\
Max. & 14.50 & 6.63 & 5.62 \\
Min. & 9.75 & 3.30 & 3.36 \\
\hline CV $(\%)$ & 7.92 & 9.76 & 9.97 \\
\hline
\end{tabular}

Based on the statistical parameters used, mainly the standard deviation and the coefficient of variation, the evaluated characteristics had low variability, considering the low values of the standard deviation. This demonstrated that the measured values were concentrated around the mean, indicating small variation between observations.

The mean values of length, width, and thickness of the seeds of D. gardneriana Tul. were close to those reported by Ferreira et al. (2001) for Dimorphandra mollis Benth., where mean seed length was $12.4 \mathrm{~mm}$ (ranging from 8.7 to $13.5 \mathrm{~mm}$ ), mean width was $5.1 \mathrm{~mm}$ (ranging from 4.3 to 5.9 $\mathrm{mm}$ ), and mean thickness was $3.9 \mathrm{~mm}$ (ranging from 3.0 to $4.8 \mathrm{~mm}$ ). However, in terms of seed length and width, these were lower than the values obtained by Lopes and Matheus (2008) for seeds of Dimorphandra wilsonii Rizz., as they recorded an average length of $17.9 \mathrm{~mm}$ (ranging from 16.0$19.0 \mathrm{~mm})$, mean width of $6.7 \mathrm{~mm}(6.0-7.0 \mathrm{~mm})$, and mean thickness of $4.3 \mathrm{~mm}(3.0-5.0 \mathrm{~mm})$.

The length, width, and thickness of Canavalia dictyota Piper seeds ranged from 14.8-17.5, 9.712.3, and 6.39.3 $\mathrm{mm}$, respectively (PRADO;
RODRIGUES, 2013), while the seeds of Clitoria fairchildiana R.A.Howard had an average length of $15.1 \pm 1.3 \mathrm{~mm}$, mean width of $13.8 \pm 1.1 \mathrm{~mm}$, and mean thickness of $2.40 \pm 0.3 \mathrm{~mm}$, with seeds predominantly between 13.8 and $15.0 \mathrm{~mm}, 13.2$ and $14,2 \mathrm{~mm}$, and 2.1 and $2.5 \mathrm{~mm}$, in length, width, and thickness, respectively (COSTA et al., 2014). In the seeds of Parkia gigantocarpa Ducke, the length ranged from 14.92 to $26.8 \mathrm{~mm}$, width from 7.85 to 12.87 , and thickness from 3.27 to $7.77 \mathrm{~mm}$, with mean values of $21.25,10.43$, and $6.15 \mathrm{~mm}$, respectively (RIBEIRO et al., 2015).

The determination of the seed size is important to verify its standardization within the species, as larger seeds are considered more vigorous and can directly influence the vigor of the seedlings produced. However, this characteristic is variable between and within the species itself; Ferreira et al. (2001) emphasized that biometric characteristics should not be used as an identification because there may be differences within the individuals of a population and between different sites of origin.

Regarding the genus Dimorphandra there are about 43 known species, with D. mollis Benth. and 
D. gardneriana Tul. considered the most important because they are frequently found in nature and are the most collected and used by the chemical and pharmaceutical industry (CUNHA et al., 2009; GONÇALVES et al., 2010). Thus, data regarding the physical and physiological characteristics of their seeds are important for seed technology, as well as for the planning of seed harvesting and seedling production in the nursery (FERREIRA et al., 2001).

\section{External morphology of the seed}

The seeds of Dimorphandra gardneriana Tul. are eurispermic, with different shapes ranging from oblong to elliptical, with a smooth forehead from brown to reddish, hard and impermeable to water, and the hilum is small, circular, located at the base of the homochromic seed, and noticeable due to a yellowing point resulting from a long, filiform funiculus. The micropyle is almost imperceptible. However, the chalaza is the most visible structure of the integument, which is a band darker than the forehead, surrounding the seed, characterizing a paquichalazal seed. The pleurogram is a lighter line than the tegument that delimits the chalaza and surrounds the whole seed, while the raphe is located on the back of the seed, characterized by a darker line, going from the base to the apex (Figure 2).

Figure 2. External aspects of D. gardneriana seed.

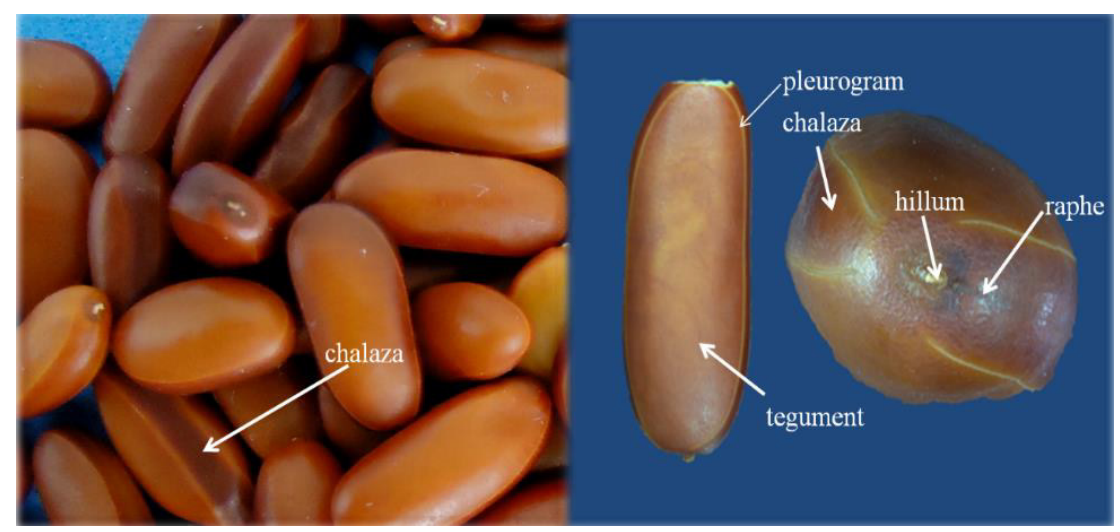

The paquichalazal seeds are coated by the paquichalaza, a complex structure constructed by the multiplication of the cells of the two integuments fused to each other and to the nucellus, with a very extensive chalaza (FERREIRA; BORGHETTI, 2004). In the ovules of the angiosperms, the chalaza corresponds to the part where the vessels that transport the sap of the funiculus pass to the nucellus at the surface of the integument and is visible in the form of a darker or lighter stain, or in the form of a dark band that can partially or totally surround the seed (BRASIL, 2009b), as confirmed in the seeds of D. gardneriana.
Seeds vary in size, shape, color, and superficial appearance of the forehead, and these variations are of great relevance in their identification, emphasizing that the integument can have a uniform coloration in shades of brown, black, gray, white, red, and yellow-green; however, for most of the seeds the predominant color is various shades of brown, with the others less frequent, and is related to the dispersion by animals (DAMIÃO FILHO, 2005; APPEZZATO-DA-GLÓRIA; CARMELLOGUERREIRO, 2012).

The external characteristics of the seeds of the species under study demonstrate similarities 
with those recorded by Ferreira et al. (2001) in Dimorphandra mollis Benth., which described the seeds as being eurispermic, oblong, reniform or broad elliptical, with a small circular hilum located at its base, chalaza surrounding them almost completely, and raphe present on its back.

The seeds of Dimorphandra wilsonii Rizz. are elliptic to reniform in shape, oblong and sometimes slightly curved, light brown to reddish in color, with a very small ellipsoid hilum located at the base of the seed, inconspicuous micropyle initially as a depression on the side of the thread and later as a scar on the back, the chalaza is visible from the base to the apex as a band darker than the forehead and surrounds the seed (LOPES; MATHEUS, 2008).

In other species of the Fabaceae family, Apuleia leiocarpa (Vogel) J.F.Macbr., Felippi et al. (2012) described an elliptical shape, with a dark brown, glossy integument. In the seeds of Inga ingoides (Rich.) Willd., Braz et al. (2012) identified an ovate shape, ranging to oblong, some with a dark green coloration and some a lighter green, thin textured forehead, and with a smooth and shiny surface. In the study by Prado and Rodrigues (2013) of Canavalia dictyota Piper, the seeds were described as symmetrical, oblong, laterally compressed; brow glabrous, coriaceous, with a brownish-brown coloration with brown spots, opaque to slightly shiny; whereas, the seeds of Clitoria fairchildiana R.A.Howard were described as exalbuminous, orbicular, flat-convex, and brown in color (COSTA et al., 2014).

\section{Internal morphology of the seed}

The seed of Dimorphandra gardneriana Tul. is un-integumented, emphasizing that in paquichalaza seeds, the integuments of the ovulum fuse, resulting in only one integument which is divided into layers. In the case of the seeds under study, the integument is divided into two distinct layers, the outer cornea being thin and the inner one a little thicker with a light brown color, strongly adhered to the reserve tissue (Figure 3A, E and F), displaying a characteristic of the Fabaceae family.

In the Fabaceae, the internal integument of the ovulum disappears and the outer layer differentiates, the epidermis remains fused and gives rise to the palisade layer, a characteristic that in some species of this family is responsible for water impermeability (COSTA et al., 2014). It should be noted that the structure of the seed coat depends on the specific characteristics of the ovum, especially with respect to the number and thickness of the integument, the arrangement of the vascular tissue, and the modifications undergone by it during the development and maturation of the seeds (CARVALHO; NAKAGAWA, 2012).

The characteristics evaluated in the tegument of the seeds of $D$. gardneriana, mainly in relation to the number of teguments, differ from those observed in Dimorphandra mollis Benth. (FERREIRA et al., 2001) and Dimorphandra wilsonii Rizz (LOPES; MATHEUS, 2008) because they are bitegumentals, although they belong to the genus Dimorphandra.

The types of integument, which may vary with the species, define the external aspect of the seed. Therefore, the way in which these teguments develop is an important characteristic of the species and its knowledge is relevant for the correct interpretation and identification of the mature seed, as its wrapping is influenced by environmental factors and may undergo modifications during the formation of the seeds (DAMIÃO FILHO, 2005; APPEZZATO-DAGLÓRIA; CARMELLO-GUERREIRO, 2012). 
Figure 3. External and internal aspects of a $D$. gardneriana seed after imbibition. $S c a l e=1 \mathrm{~cm}$.

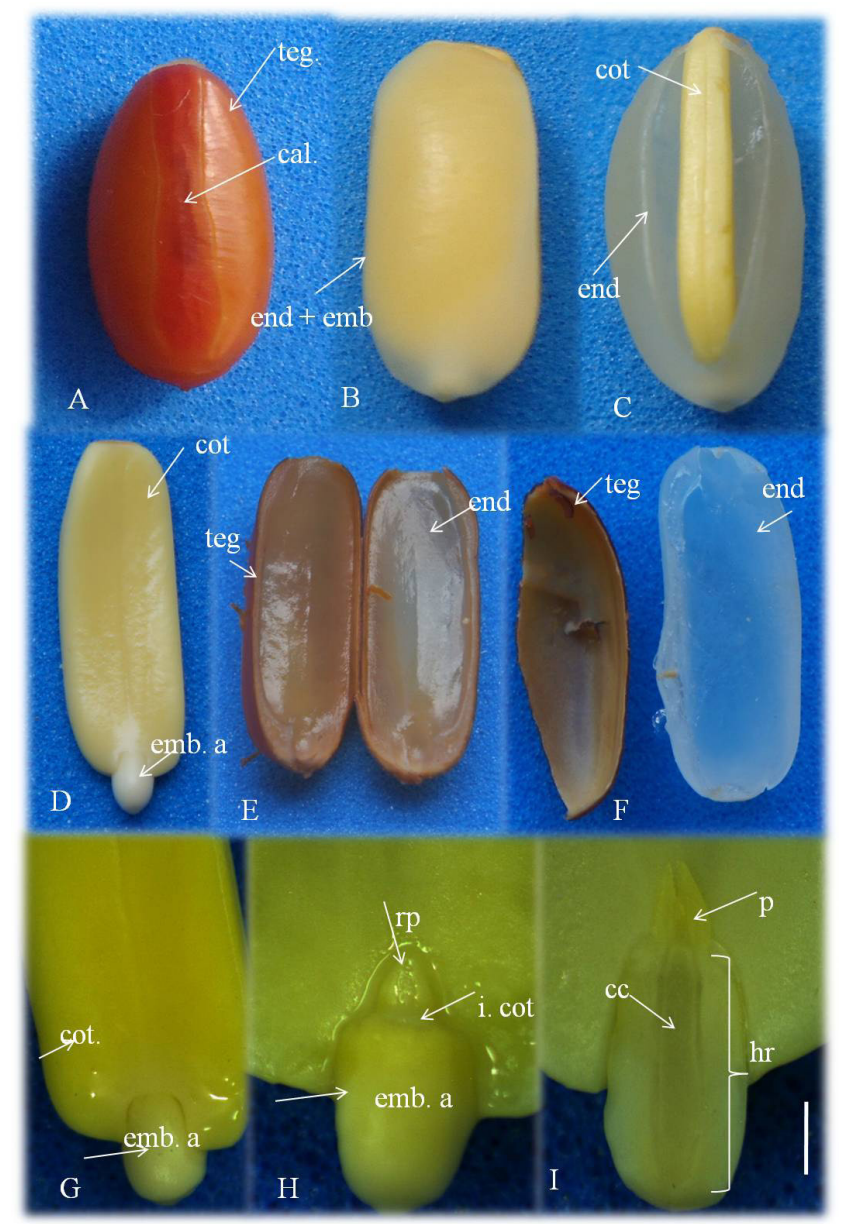

Ventral view of seed (A), dorsal view of seed without tegument (B), ventral view of seed without tegument (C), embryo (D), longitudinal cut of seed without embryo (E), endosperm separated from tegument (F), external view of the embryonic axis with the cotyledon $(\mathrm{G})$, internal view of the embryonic axis $(\mathrm{H})$, longitudinal section of the embryonic axis (I). End + emb - endosperm + embryo; cal - chalaza; teg - tegument; end - endosperm; cot - cotyledons; embr. a. - embryonic axis; i.cot - insertion of the cotyledon; rp - region of the plumule; hr - hypocotyl-radicle axis; cc - central cylinder; $\mathrm{p}$ - plumule. Scale bar $=5 \mathrm{~cm}$.

The seeds of $D$. gardneriana are albuminous, with an abundant endosperm occupying most of the seed, and in a dry state it has a corneous texture; however, when hydrated it becomes gelatinous and colorless, which totally envelops the embryo except on the back of the seed (Figure 3B and C). The embryo is dominant, axial, invaginated, with two opposite cotyledons that are straight, foliaceous, smooth and equal, oblong, yellowish-colored, membranous, with a slightly visible central rib and invagination at the base, and at the insertion point of the hypocotyl-radicle axis (Figure 3D and G). The embryonic axis is short, straight, cylindrical, and small in relation to cotyledon size, cream-colored, most of which is occupied by the hypocotyl-radicle axis, with a visible central cylinder, a rounded radicular pole, and a rudimentary plume (Figure $3 \mathrm{H}$ and I).

The presence of a mucilaginous endosperm of corneal consistency when dry and gelatinous after wetting is characteristic of seeds of certain species of the Fabaceae family, such as the seeds of Dimorphandra mollis Benth. (FERREIRA et al., 2001) and Dimorphandra wilsonii Rizz (LOPES; MATHEUS, 2008), which showed similar 
characteristics to those identified for the albumen of the seeds under study. According to Appezzatoda-Glória and Carmello-Guerreiro (2012), in this type of endosperm, the cell walls can be formed by several compounds that absorb water when in contact and swell to form a mucilaginous mass.

For seeds of Inga ingoides (Rich.) Willd., Braz et al. (2012) described an embryo with flat-convex, crass, dark green, cotyledons, arranged parallel to the hypocotyl-radicle axis that is straight, short, hairy, and hidden inside the cotyledons with the rudimentary plumule. As for the seed embryo of Parkia gigantocarpa Ducke, it is linear-axial, with cotyledons crass, straight, convex, and dominant, and at the base, there is a groove where the insertion point of the cotyledons in the embryonic axis is located (RIBEIRO et al., 2015). In seeds of Bowdichia virgilioides Kunth, the embryo is invaginated, filling the entire seed, being considered total in size, of green coloration, ellipsoid format, cotyledons with storage, and a clear delineation between the hypocotyl-radicle axis and imperceptible plume (ALBUQUERQUE et al., 2015).

\section{Imbibition and germination curve}

The imbibition curve, amount of water absorbed, germination, and formation of normal seedlings of D. gardneriana seeds are shown in Figure 4A-D. Before the imbibition, the seeds had a water content of $6.9 \%$ and an initial weight of $6.37 \mathrm{~g}$, remaining almost constant in the first $6 \mathrm{~h}$ and showing a small variation during the $12 \mathrm{~h}$ of imbibition, with a relatively slow imbibition until $12 \mathrm{~h}$, with 6.86 grams, that is, only 0.49 grams of water was absorbed by the seeds in this period (Figure 4A).

Figure 4. Imbibition curve (A), quantity of imbibed water (B), seed germination (C) and formation of normal seedlings (D) of D. gardneriana.

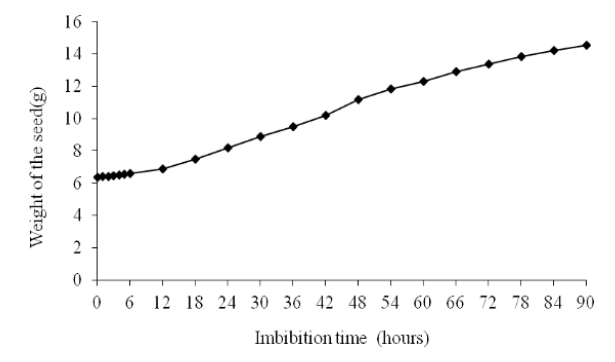

A

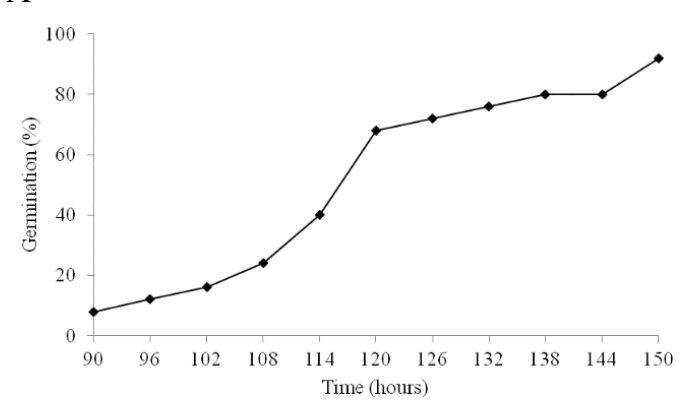

$\mathrm{C}$

The amount of water absorbed can be seen in Figure 4B, which demonstrates a behavior similar to that observed for seed weight. It was not possible to

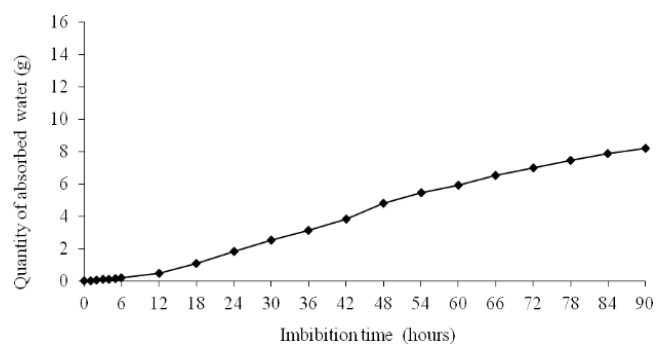

B

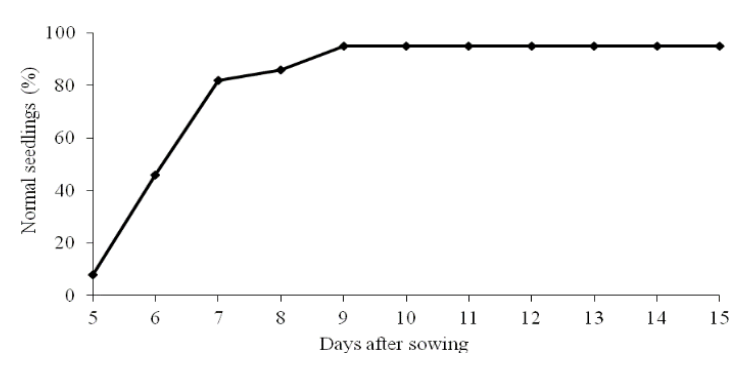

D

show the three stages of germination clearly as the seeds absorb water continuously until the moment of germination (Figure 4A-B). 
Germination started after $90 \mathrm{~h}$ of imbibition, characterizing stage III of the germination and, until $108 \mathrm{~h}$ this percentage remained low $(7 \%)$, reaching its maximum $(97 \%)$ at $150 \mathrm{~h}$ when the primary root emerged from all seeds. The development of normal seedlings began on the 5th day after sowing, when the hypocotyl had reached $2 \mathrm{~cm}$ and maximum size at $15 \mathrm{~d}$, when all seedlings were observed to be developed with a perfect root and shoot (Figure 4C-D).

In the study of water uptake by seeds, Marcos Filho (2015) stated that this process occurs in three phases; in phase I, a rapid entry of water into the seed is evident as a function of the difference of the water potential gradient between the seeds and the substrate in the first hours. However, for the seeds studied, this characteristic was not observed because the rate of absorption was slow in the first $12 \mathrm{~h}$. This behavior may be related to the seed morphology, together with the chemical composition of the reserve tissue, as the endosperm completely envelops the embryo as a protective layer and owing to its composition may have made the intake of water initially slow as can be seen in Figure 3B.

Phase II is the longest and the rate of water absorption becomes slow as the preparatory metabolism for the emergence of the primary root occurs, while in phase III, with the metabolism activated, there is a reduction of water potential and an increase in uptake of embryonic axis growth (MARCOS FILHO, 2015). In the case of $D$. gardneriana seeds, phase III was observed after 90 $\mathrm{h}$ of imbibition when the emergence of the primary root was verified (Figure 4C).

The behavior of the seeds in relation to imbibition is variable within the species; however, in the seeds of Dimorphandra wilsonii Rizz., Lopes and Matheus (2008) reported a behavior similar to that verified for the seeds of $D$. gardneriana with imbibition initially slow and not being possible to distinguish clearly between the three stages of germination. According to Albuquerque et al. (2009) the imbibition speed is variable with the characteristics of the seeds of each species, among them the chemical composition and the permeability of the integument; thus, the germination of seeds consists in the reactivation of the growth of the embryonic axis by means of an ordered sequence of metabolic events that results in the rupture of the integument by the primary root.

In the study of seed germination in Clitoria fairchildiana R.A.Howard, Costa et al. (2014) did not observe the occurrence of phase III of imbibition and attributed this to the deterioration of the seeds. On the other hand, Albuquerque et al. (2015) identified the three phases of the imbibition in the seeds of Bowdichia virgilioides Kunth and observed the occurrence of phase III when the seeds returned to absorb water, which culminated with the root protrusion after $48 \mathrm{~h}$ of imbibition.

\section{Morphology of germination, normal and abnormal seedling, and young plant}

The germination of the seeds of Dimorphandra gardneriana Tul. is epigeal (owing to hypocotyl growth, the cotyledons are raised out of the soil and become free of the integument), phaneroconuclear, beginning after $90 \mathrm{~h}$ of imbibition, characterized by the emergence of a primary root (which breaks the integument in the basal region of the seed), that is whitish in color, short, thick, and glabrous (Figure 5A-B). On the 5th and 6th days after sowing, the development of the hypocotyl is observed, which initially has the same shade as the root and later becomes light green, is cylindrical, glabrous, thick, and initially curved, and when it elevates the cotyledons out of the substrate, the colon is well defined and very noticeable by the dilation between the primary and hypocotyl roots (Figure 5C-D). The foliaceous cotyledons become light green and open to the development of the epicotyl, also light green in color and cylindrical, the apical bud is glabrous, appears before the complete expansion of 
the protophyllus, the secondary roots are thin, short, cylindrical, and the same color as the primary root (Figure 5E).

The germination type is one of the most relevant characteristics to differentiate species (GURGEL et al., 2012), with epigeal germination being the most common among Fabaceae. Seed germination of Clitoria fairchildiana R.A.Howard was classified by Costa et al. (2014) as phaneroconuclear and epigeal, starting on the fifth day after sowing.

Figure 5. Aspects of germination and normal seedlings of D. gardneriana in a period of $90 \mathrm{~h}$ (A-B), five and six days (C-D), and thirteen days after sowing (E).

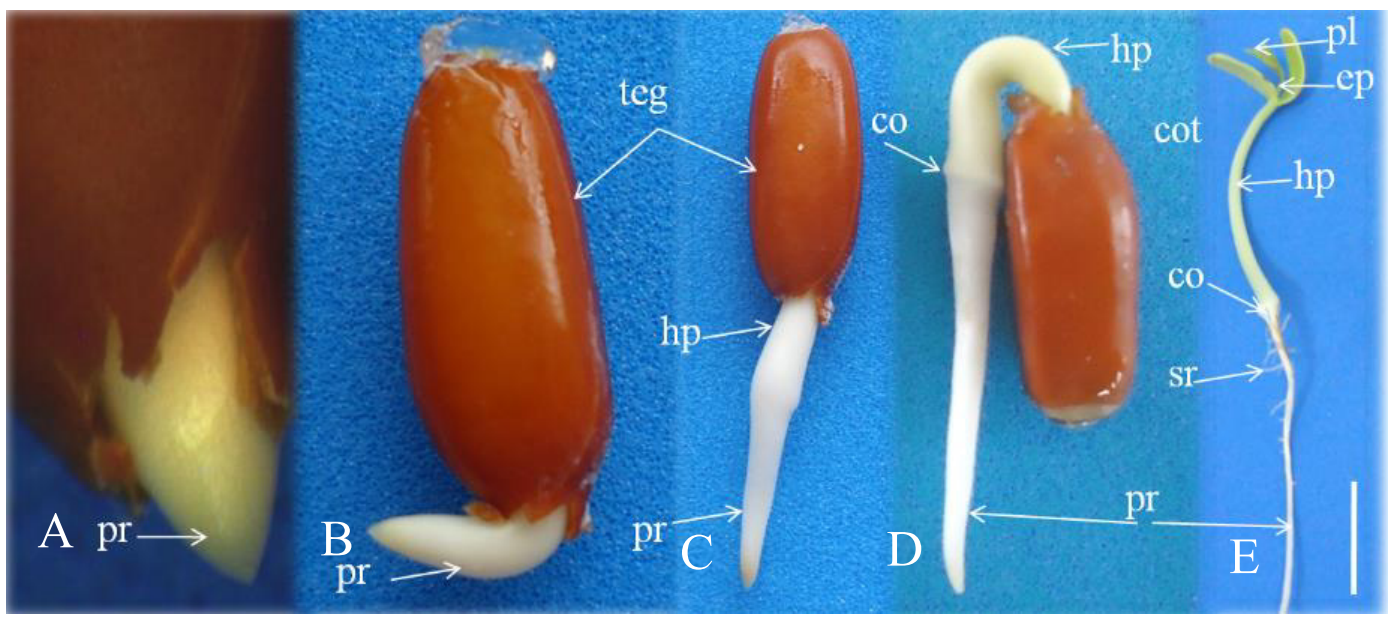

Pr - primary root; pl - primary leaves; c - cotyledons; teg - tegument; co - collet; ep - epicotyl; hp - hypocotyl; $\mathrm{sr}-$ secondary root. Scale bar $=1 \mathrm{~cm}$.

Germination of the seeds of Parkia gigantocarpa Ducke was described as epigeal phaneroconuclear, beginning 2-5 days after sowing (RIBEIRO et al., 2015). For the seeds of Bowdichia virgilioides Kunth, Albuquerque et al. (2015) found epigeal, phanerocotiledonar germination. Similarly, Ferreira and Barreto (2015) classified the germination of the seeds of Caesalpinia echinata Lam. as epigeal phanerocotiledonar, beginning on the 3rd day with the protrusion of the primary root.

Abnormal seedlings are characterized by the absence or malformation of the essential structures at the beginning of germination, and among the abnormalities present in $D$. gardneriana seedlings were the absence of a primary root and malformed and undeveloped aerial part, with the cotyledons trapped to the tegument (Figure $6 \mathrm{AC}$ ). The absence of a primary root and presence of few secondary roots were also observed, besides the presence of cracks in the root continuing to the stem, which continued developing until the end of the germination test; however, they were weak and incapable of establishing themselves in field conditions.

Abnormal seedlings result from the presence of damaged tissues, poorly formed embryos, or the presence of pathogens. In the case of the damages, these are considered one of the most limiting factors for the viability of the seeds and, depending on the intensity, can reach different parts of the seed, especially the embryo, which contributes to the formation of abnormal and weak seedlings, incapable of growing and surviving in the field (CARVALHO; NAKAGAWA, 2012). 
Figure 6. Aspects of abnormal seedlings of D. gardneriana at eight (A), thirteen (B), and fifteen days after sowing (C).

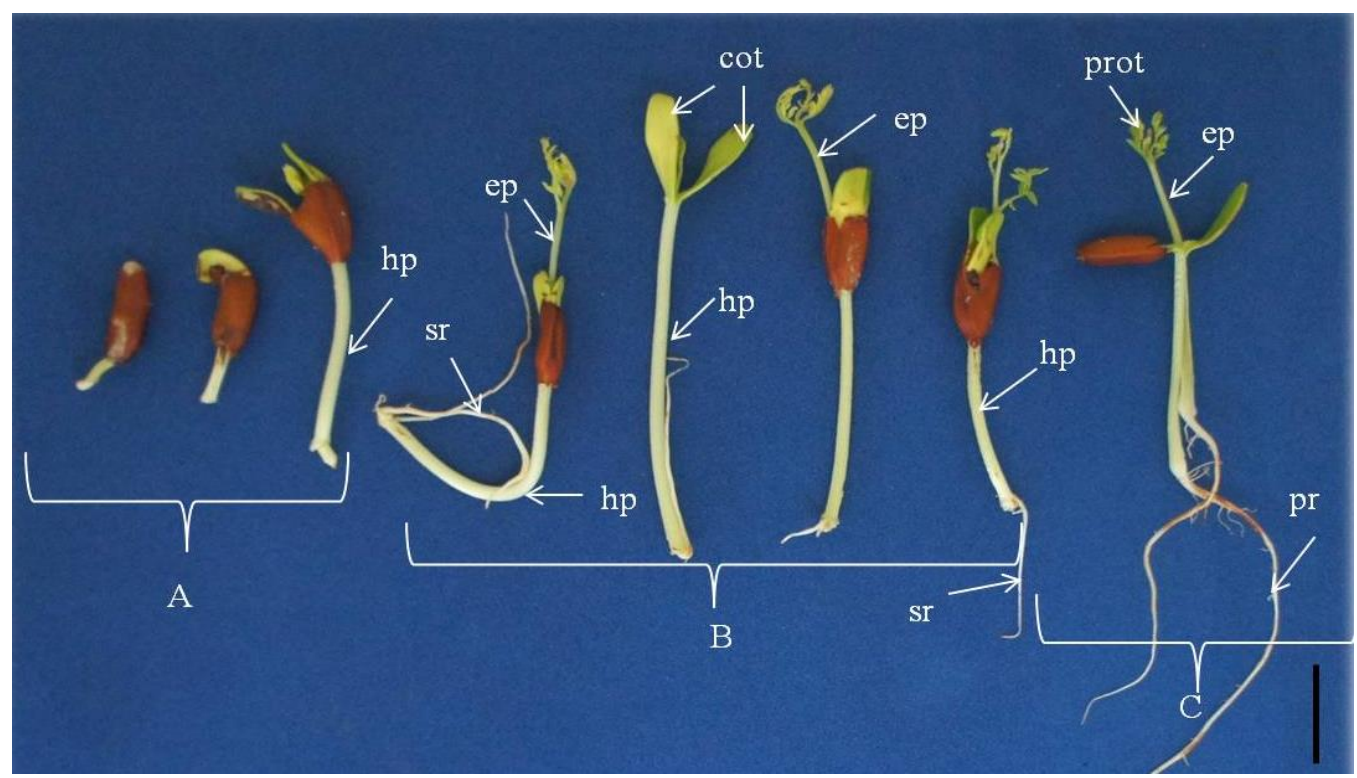

Pr - primary root; c - cotyledons; ep - epicotyl; hp - hypocotyl; sr - secondary root; prot - protophilus. Scale bar $=3 \mathrm{~cm}$.

During the germination test of the seeds of Cedrelinga catenaeformis Ducke. abnormal seedlings were found (MELO; VARELA, 2006), as if they were correlated with a small local population, which may have occurred in a function of high rate of inbreeding.

During the germination test of the seeds of Cedrelinga catenaeformis (Ducke) abnormal seedlings were found (MELO; VARELA, 2006), which were correlated with the small population at the collection site, may have occurred due to high rates of inbreeding. However, for the evaluated species, this abnormality may have occurred due to damage to the seeds at the time of processing, since the extraction was done by breaking the fruits with mallets and this could have damaged them.

On the 15th day, when the seedling was well developed, there was greater elongation of the epicotyl that together with the cotyledons were of a light green coloration; the protophylls were alternating and composed of leaflets at the beginning of expansion (Figure 7A-B). Toward the apex, the stem was herbaceous, completely covered with simple, long, reddish hairs at the tips, being more numerous at the apex, visible only under the microscope. The hypocotyl was long, light green, cylindrical, being thicker and lighter in color at the base near the collet, the main root was well developed, yellowish in color, with secondary roots developing at the lateral, semi-opposing, clear, and well distributed along the primary root.

At $60 \mathrm{~d}$, the young plant had a well-developed root system, with a primary axis, pivoting, sinuous, cylindrical, and yellowish to light rusty in color. The secondary roots were more elongated, and in greater number, thin, sinuous, rust-clear with a yellowish and cylindrical root cap, with similar tertiary roots (Figure 7C). The stem of the plant was straight, cylindrical, dark green and brownish owing to the transition from herbaceous to woody; the cotyledons in the senescence phase were yellowish. The leaves were alternate, paripinnate, petiolate, with expanded leaflets, the oldest of which were dark green on both faces, while the young leaflets were light green, with a short petiolate, opposite, sometimes alternate, small, glabrous, oblong, peninérveos, with the main vein quite evident, printed on both faces. 
Figure 7. Aspects of the seedlings and young plants of D. gardneriana. Details of structures (A), seedling with 15 (B) and 60 days after sowing $(\mathrm{C})$.

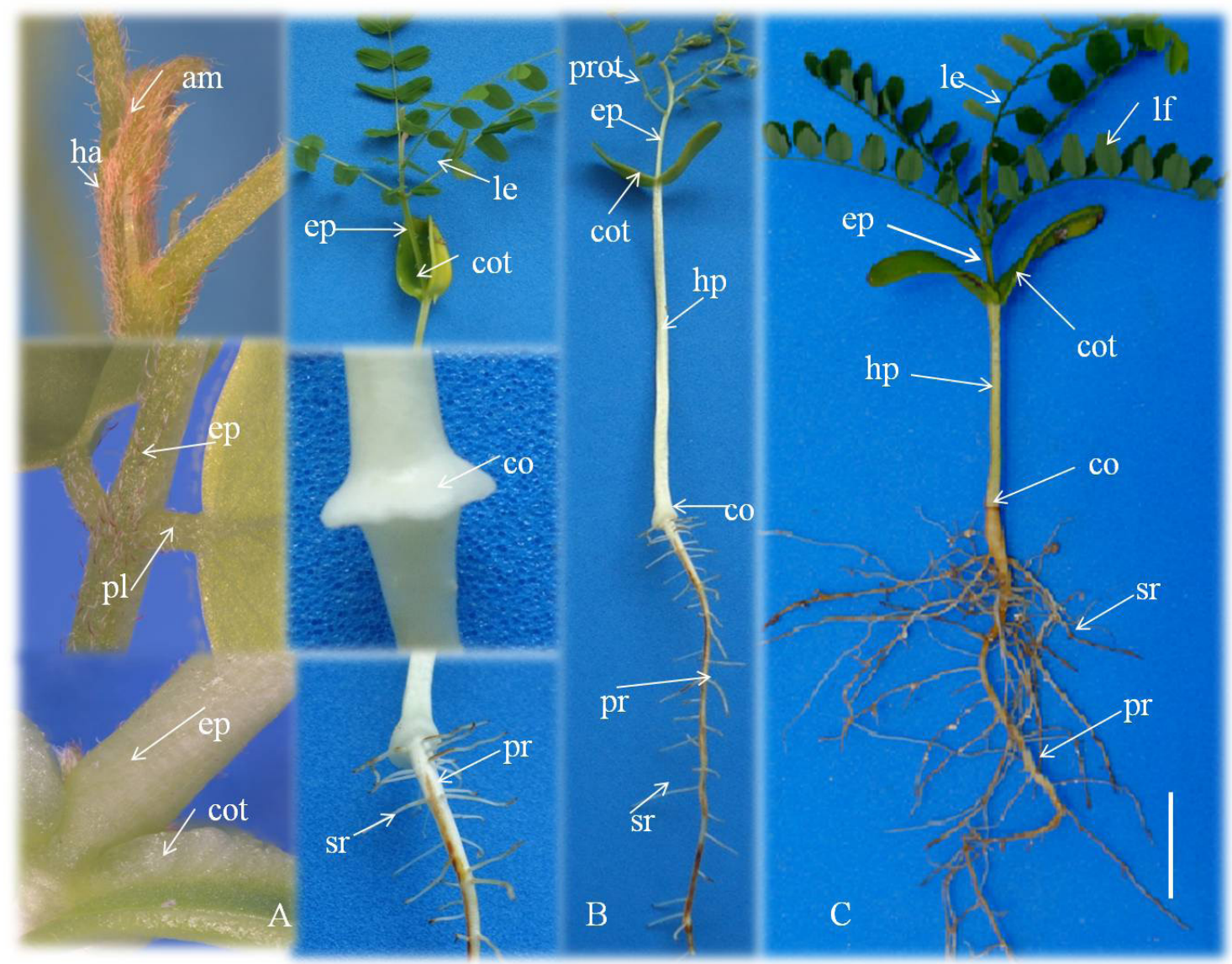

am - apical meristem; ha - hairs; co - collet; ep - epicotyl; hp - hypocotyl; cot - cotyledons; prot - protophilus; h - root hair; le - leaves; lf - leaflets; $\mathrm{pr}$ - primary root; $\mathrm{sr}$ - secondary root. Scale bar $=3 \mathrm{~cm}$.

The characteristics of the young plants of $D$. gardneriana resemble those described by Ferreira et al. (2001) for Dimorphandra mollis Benth.; such as, the presence of epicotyl hairs, apical buds, but some differences are the apparently tuberous pivotal root and the visibility of the hairs to the naked eye. However, in Dimorphandra wilsonii Rizz, Lopes and Matheus (2008) found epigeal phaneroconuclear germination, but the structure of the apex of the seedling was similar to that of Dimorphandra mollis Benth., both were hairy on the ventral surface.

The morphological characteristics evaluated in seedlings and young plants of D. gardneriana were homogeneous; however, in the adult phase they could undergo changes and differ from the young phase. In the morphological study of young plants and seedlings of Dimorphandra mollis Benth., Ferreira et al. (2001) reported that the morphological aspects, in the different phases studied, were also constant, permitting their use in taxonomic studies. It is important to highlight that the morphological characterization provides subsidies to differentiate species and characterize ecological aspects of the plant, such as the dispersion, establishment, and phase of ecological succession.

In this way, the differences between the plants, as well as the variations they may have in common, are susceptible to large-scale evaluation by the morphological characters, which are exhibited 
by structural components of the plants and are important for their dependability (CUNHA; FERREIRA, 2003).

\section{Conclusions}

Most of the morphological characteristics identified in the plants of $D$. gardneriana resemble those observed for other species of the same genus.

The seeds of Dimorphandra gardneriana Tul., are medium sized, have an average length of 11.95 $\mathrm{mm}$, a width of $5.33 \mathrm{~mm}$, and thickness of $4.3 \mathrm{~mm}$, are un-integumented, with a hard tegument and impermeable to water.

The process of imbibition of the seeds is initially slow, and the three-phase curve of the imbibition is not visible, the germination is epigeal, phaneroconuclear, beginning on the 5th day after sowing.

\section{References}

ABUD, H. F.; GONÇALVES, N. R.; PEREIRA, M. S.; PEREIRA, D. S.; REIS, R. G. E.; BEZERRA, A. M. E. Germination and morphological characterization of the fruits, seeds, and seedlings of Pilosocereus gounellei. Brazilian Journal of Botany, São Paulo, v. 35, n. 1, p. 11-16, 2012. DOI: 10.1590/S0100-84042012000100003

ALBUQUERQUE, A. N.; ALBUQUERQUE, M. C. F.; MENDONÇA, E. A. F.; MARIANO, D. C.; OKUMURA, R. S.; JUNIOR COLETTI, A. Aspectos morfológicos de frutos, sementes e plântulas de sucupira preta. Revista de Ciências Agrárias, Jerônimo Monteiro, v. 58, n. 3, p. 233-239, 2015. DOI: /10.4322/rca.1720

ALBUQUERQUE, K. S.; GUIMARÃES, R. M.; ALMEIDA, I. F.; CLEMENTE, A. C. S. Alterações fisiológicas e bioquímicas durante a embebição de sementes de sucupira-preta (Bowdichia virgilioides Kunth.). Revista Brasileira de Sementes, Lavras, v. 31, n. 1, p. 12-19, 2009.

APPEZZATO-DA-GLÓRIA, B.; CARMELLOGUERREIRO, S. M. Anatomia vegetal. 3. ed. Viçosa, MG: Ed. UFV, 2012. 406 p.

BRASIL. Ministério da Agricultura, Pecuária e Abastecimento. Glossário ilustrado de morfologia.
Secretaria de Defesa Agropecuária. Brasília: MAPA/ ACS, 2009b. 406 p.

BRASIL. Ministério da Agricultura, Pecuária e Abastecimento. Regras para análise de sementes. Secretaria de Defesa Agropecuária. Brasília: MAPA/ ACS, 2009a. 395 p.

BRAZ, M. S. S.; FREITAS, S. L. S.; CAMPOS, M. A. L.; MIRANDA, D. D. O. A.; COSME, M. C. Caracterização morfológica do fruto, semente, plântula e planta jovem e germinação de Inga ingoides (Rich) Willd. Cerne, Lavras, v. 18, n. 3, p. 353-360, 2012.

CARVALHO, N. M.; NAKAGAWA, J. Sementes: ciência, tecnologia e produção. 5. ed. Jaboticabal: FUNEP, 2012. $590 \mathrm{p}$.

COSTA, L. G.; SILVA, A. G.; GOMES, D. R. Morfologia de frutos, sementes e plântulas, e anatomia das sementes de sombreiro (Clitoria fairchildiana). Revista de Ciências Agrárias, Jerônimo Monteiro, v. 57, n. 4, p. 414-421, 2014. DOI: /10.4322/rca.1596

CUNHA, M. C. L.; FERREIRA, R. A. Aspectos morfológicos da semente e do desenvolvimento da planta jovem de Amburana cearensis (Arr. Cam.) A.C. Smith - cumaru - Leguminosae Papilionoideae. Revista Brasileira de Sementes, Londrina, v. 25, n. 2, p. 89-96, 2003.

CUNHA, P. L. R.; PAUlA, R. C. M.; FEITOSA, J. P. A. Polissacarídeos da biodiversidade brasileira: uma oportunidade de transformar conhecimento em valor econômico. Química Nova, São Paulo, v. 32, n. 3, p. 649660, 2009.

DAMIÃO FILHO, C. F. Morfologia vegetal. 2. ed. rev. e ampl. Jaboticabal: FUNEP, 2005. 172 p.

DONADiO, N. M. M.; DEMATTÊ, M. E. S. P. Morfologia de frutos, sementes e plântulas de canafístula (Peltophorum dubium (Spreng.) Taub.) e jacarandáda-bahia (Dalbergia nigra (Vell.) Fr.All. ex Benth.). Fabaceae. Revista Brasileira de Sementes, Londrina, v. 22, n. 1, p. 64-73, 2000.

DUARTE, M. M.; MILANI, J. E. F.; BLUM, C. T.; NOGUEIRA, A. C. Germinação e morfologia de sementes e plântulas de Albizia edwallii (Hoehne) Barneby \& J. W. Grimes. Revista Caatinga, Mossoró, v. 28, n. 3, p. 166-173, 2015.

FELIPPI, M.; MAFFRA, C. R. B.; CANTARELLI, E. B.; ARAÚJO, M. M.; LONGHI, S. J. Fenologia, morfologia e análise de sementes de Apuleia leiocarpa (Vogel) J. F. Macbr. Ciência Florestal, Santa Maria, v. 22, n. 3, p. 477491, 2012. 
FERREIRA, A. G.; BORGHETTI, F. Germinação: do básico ao aplicado. Porto Alegre: Artmed, 2004. 323 p.

FERREIRA, D. F. SISVAR: a computer statistical analysis system. Ciência e Agrotecnologia, Lavras, v. 35, n. 6, p. 1039-1042, 2011. DOI: 10.1590/S141370542011000600001

FERREIRA, R. A.; BARRETTO, S. S. B. Caracterização morfológica de frutos, sementes, plântulas e mudas de pau-brasil (Caesalpinia echinata Lamarck). Revista Arvore, Viçosa, MG, v. 39, n. 3, p. 505-512, 2015.

FERREIRA, R. A.; BOTELHO, S. A.; DAVIDE, A. C.; MALAVASI, M. M. Morfologia de frutos, sementes, plântulas e plantas jovens de Dimorphandra mollis Benth. - faveira (Leguminosae-Caesalpinioideae). Revista Brasileira de Botânica, São Paulo, v. 24, n. 3, p. 303-309, 2001.

GONÇALVES, A. C.; REIS, C. A. F.; VIEIRA, F. A.; CARVALHO, D. Estrutura genética espacial em populações naturais de Dimorphandra mollis (Fabaceae) na região Norte de Minas Gerais, Brasil. Revista Brasileira de Botânica, São Paulo, v. 33, n. 2, p. 325332, 2010.

GROTH, D.; LIBERAL, O. H. T. Catálogo de identificação de sementes. Campinas: Fundação Cargil, 1988. $182 \mathrm{p}$.

GURGEL, E. S. C.; SANTOS, J. U. M.; LUCAS, F. C. A.; BASTOS, M. N. C. Morfologia de plântulas de Leguminosae e o potencial sistemático. Rodriguésia, Rio de Janeiro, v. 63, n. 1, p. 65-73, 2012.

LOPES, J. C.; MATHEUS, M. T. Caracterização morfológica de sementes, plântulas e da germinação de Dimorphandra wilsonii Rizz. - faveiro-de-Wilson (Fabaceae Caesalpinioideae). Revista Brasileira de Sementes, Lavras, v. 30, n. 1, p. 96-101, 2008.

MARCOS FILHO, J. Fisiologia de sementes de plantas cultivadas. Piracicaba: FEALQ, 2015. 659 p.

MELO, M. F. F.; VARELA, V. P. Aspectos morfológicos de frutos, sementes, germinação e plântulas de duas espécies florestais da amazônia. I. Dinizia excelsa Ducke (angelim pedra). II Cedrelinga catenaeformis Ducke (cedrorana) - Leguminosae: Mimosoideae. Revista Brasileira de Sementes, Lavras, v. 28, n. 1, p. 54-62, 2006.

MELO, M. G. G.; MENDONÇA, M. S.; MENDES, A. M. S. Análise morfológica de sementes, germinação e plântulas de jatobá (Hymenaea intermedia Ducke var. adenotricha (Ducke) Lee \& Lang.) (Leguminosaecaesalpinioideae). Acta Amazonica, Manaus, v. 34, n. 1, p. 9-14, 2004.
MONTANO, H. G.; SILVA, G. S.; ROCHA, R. C.; JIMENEZ, N. Z. A.; PEREIRA, R. C.; BRIOSO, P. S. T. Phytoplasma in fava d'anta tree (Dimorphandra gardneriana) in Brazil. Bulletin of Insectology, Bolonha, v. 60 , n. 2, p. 147-148, 2007.

PIRES, N. R.; CUNHA, P. L. R.; PAULA, R. C. M.; FEITOSA, J. P. A.; JAMACARU, F. V. F.; MORAES FILHO, M. O. Viscoelásticos oftálmicos: comparação entre os comerciais e formulações de galactomanana de Dimorphandra gardneriana. Química Nova, São Paulo, v. 33, n. 8, p. 1709-1713, 2010.

PRADO, E. S.; RODRIGUES, R. S. Morfologia de frutos, sementes e plântulas de Canavalia dictyota Piper (Leguminosae, Papilionoideae). Boletim do Museu Integrado de Roraima, Roraima, v. 7, n. 1, p. 28-34, 2013.

REIS, A. R. S.; FREITAS, A. D. D.; LEÃO, N. V. M.; SANTOS FILHO, B. G. Morphological aspects of fruits, seeds, and seedlings, and anatomy of seedlings of Apuleia molaris spruce ex benth. Journal of Seed Science, Londrina, v. 38, n. 2, p. 118-128, 2016. DOI: $0.1590 / 2317-1545 \mathrm{v} 38 \mathrm{n} 2158472$

RIBEIRO, J. W. F.; OLIVEIRA, A. K. M.; RODRIGUES, A.P.A.C.; RONDON, E. V. Germination and morphology of seeds and seedlings of Parkia gigantocarpa Fabaceae: Mimosoidae. Floresta, Curitiba, v. 45, n. 2, p. 303-314, 2015. DOI: 10.5380/rf.v45i2.34504

RIBEIRO-SILVA, S.; SCARIOT, A.; MEDEIROS, M. B. Uso e práticas de manejo de faveira (Dimorphandra gardneriana Tul.) na região da chapada do Araripe, Ceará: implicações ecológicas e sócio-econômicas. Biodiversidade Brasileira, Brasília, v. 2, n. 2, p. 65-73, 2012.

RODRIGUES, A. C. C.; OSUNA, J. T. A.; OLIVEIRA, S. R.; QUEIROZ, D.; RIOS, P. S. Biometria de frutos e sementes e grau de umidade de sementes de angico (Anadenanthera colubrina (Vell.) Brenan Var. cebil (Griseb.) Altschul) procedentes de duas áreas distintas. Revista Científica Eletrônica de Engenharia Florestal, Garça, v. 4, n. 8, p. 1-15, 2006.

SILVA, K. B.; ALVES, E. U.; BRUNO, R. L. A.; MATOS, V. P.; GONÇALVES, E. P. Morfologia de frutos, sementes, plântulas e plantas de Erythrina velutina Willd., Leguminoseae - Papilionideae. Revista Brasileira de Sementes, Pelotas, v. 30, n. 3, p. 104-114, 2008.

URSULINO, M. M. Tecnologia de sementes de Dimorphandra gardneriana Tulasne. 2013. Dissertação (Mestrado em Agronomia) - Centro de Ciências Agrárias, Universidade Federal da Paraíba, Areia. 